\title{
Fisheries-Based Ecotourism in Bangladesh: Potentials and Challenges
}

\author{
Mohammad Mojibul Hoque Mozumder 1,*(D), Mohammad Muslem Uddin ${ }^{2}$, Petra Schneider ${ }^{3}$ (i), \\ Mohammad Mahmudul Islam ${ }^{4}\left(\right.$ ) and Md. Mostafa Shamsuzzaman ${ }^{4}$ \\ 1 Helsinki Institute of Sustainability Science (HELSUS), Fisheries and Environmental Management Group, \\ Faculty of Biological and Environmental Sciences, University of Helsinki, 00014 Helsinki, Finland \\ 2 Institute of Marine Sciences and Fisheries, University of Chittagong, Chittagong 4331, Bangladesh; \\ mmu_ims76@yahoo.com \\ 3 Department for Water, Environment, Civil Engineering and Safety, University of Applied Sciences \\ Magdeburg-Stendal, Breitscheidstraße 2, D-39114 Magdeburg, Germany; petra.schneider@hs-magdeburg.de \\ 4 Department of Coastal and Marine Fisheries, Sylhet Agricultural University, Sylhet 3100, Bangladesh; \\ mahmud.cmf@sau.ac.bd (M.M.I.); sakil.cmf@sau.ac.bd (M.M.S.) \\ * Correspondence: mohammad.mozumder@helsinki.fi; Tel.: +3-584-0049-1395
}

Received: 6 August 2018; Accepted: 18 September 2018; Published: 20 September 2018

\begin{abstract}
Recreational fishing trips constitute a significant part of the tourism business in many countries. Linking fisheries to tourism can be both a response to the need to create innovative tourism products and the need to find new sources of income for fisheries to make them more profitable and sustainable. This leads to the question of whether Bangladesh can be developed as a Fisheries-Based Ecotourism (FbE) destination. Though several types of research have been done concerning the prospects of ecotourism in Bangladesh, the feasibility of $\mathrm{FbE}$ specifically remains under-studied. Based on a literature review and stakeholder interviews, this study explores the concept of $\mathrm{FbE}$ in a Bangladeshi context and its potential impacts on socio-economic community life as well as on the environment. This paper makes the case that the diversified topography of Bangladesh-including the riverine flat alluvial plains, hills and valleys, deciduous and evergreen forests, lakes, seashores, and beaches-is ripe with potential for FbE development. With its focus on the prospects and challenges of $\mathrm{FbE}$ development in Bangladesh, this paper could provide a useful reference point for future discourse on these sorts of cultural and economic strategies.
\end{abstract}

Keywords: Bangladesh; fisheries; ecotourism; policies; marketing; sustainable development; employment

\section{Introduction}

Ecotourism focuses on the enhancement of natural systems through tourism [1]. The International Ecotourism Society (TIES), defines ecotourism as "responsible travel to natural areas that conserves the environment, sustains the well-being of the local people and involves interpretation and education" [2]. Ecotourism thus involves environment-friendly support for local livelihood diversification and nature conservation sustainably [3]. Ecotourism can also contribute to increasing sustainable productivity, infrastructure development in remote areas and boosting the employment rate in local communities [4].

Apart from being an important protein source and supporting vital ecosystem functions, fishing also provides recreational benefits [5,6]. Many tourists are losing interest in the traditional sun, sand and sea packages and are instead looking to experience something more actively engaging. For some, fishing activities and exploring cultures with an ancient fishing heritage can be significant attractions [7]. Thus Fisheries-Based Ecotourism $(\mathrm{FbE})$ has received increasing attention in recent years. This can involve a wide range of activities, including recreational spin-cast fishing, excursions 
in professional fishing vessels, learning from locals about alternative fishing methods and fishing gear, game fishing and discovering exotic marine environments and their biodiversity [8].

While there is no universal definition for fishing tourism, recreational fishing ranks as one of the most popular leisure activities in the world today. It is both an integral part of modern culture and an important sector within the global tourism industry [9]. The primary source of global fishing tourists is the United States, and recreational fishing adds approximately $\$ 115$ billion annually and 800,000 jobs [10,11]. In North America, fees paid by recreational fishers in the forms of excise taxes, fishing licenses, additional license stamps to fish in restricted areas, and equipment registration fees directly support fisheries management, conservation efforts, and outdoor recreation opportunities [12]. Australians and New Zealanders are also avid anglers though, and they currently account for around $70 \%$ of fishing tourism in Pacific Island countries [13]. Recreational fishing is also popular in Asian countries which are home to some of the world's highest altitude river systems, including Malaysia, Thailand, Mongolia, the Maldives, China, Japan, Sri Lanka, Taiwan, and India [14].

In Europe, sports fishing is an over a $€ 20$ billion per year business, between money spent in tackle shops and then on boats, electronics, clothing, fishing vacation travel expenses, fishing licenses, charter boats, fishing guides, hotels, boat fuel and services, and port taxes [15]. In recent years sports fishing tourism has been established there as a strategy to compensate for fishers' short-term losses related to the establishment of Marine Protected Areas (MPAs) [16]. Another traditional fishing ground for Europeans is the North Sea. However, most of the primary fishing tourism sites in Europe are on inland rivers: the Laxá River in Iceland, the Alta River in Norway, Rio Ebro in Spain and the rivers of Finnish Lapland. Significant European ocean fishing sites include Scotland's Orkney Islands, the West Coast of Ireland and the Canary Islands. The alpine lakes of Switzerland and northern Italy are also famous for their fishing tourism [17].

$\mathrm{FbE}$ tourism is a new type of proposal for the tourism industry, both for established coastal tourism destinations, where innovation and differentiation strategies are necessary to survive and to maintain their markets within the fierce international competition in the field; and for hinterland destinations, where the development of tourism can serve as a means of supporting otherwise endangered local communities and traditions by marketing them as local attractions [18]. Combining the attractions of fishing tourism with the principles of Ecotourism, it attempts to provide environmentally responsible and culturally sensitive forms of travel to fishery areas and on recreational fishing expeditions within these areas [19]. By offering fishers an opportunity to supplement their incomes and by encouraging them to maintain the traditional character of their environment as a condition for drawing in tourists, $\mathrm{FbE}$ can help encourage more sustainable growth patterns in the artisanal fishing sector in particular, and it can offer fresh hope for the preservation of this way of life [20]. Fishing tourists with the opportunity to come aboard local fishing boats as paying guests, allowing them to appreciate the natural beauty of these aquatic vistas from an unobtrusive perspective right on the water. Local fishers, in turn, can act as tour guides and expert instructors in traditional fishing methods and equipment, the marine environment and fishing heritage of the local community [21]. These excursion packages can be further developed to include preparation of traditional local cuisine onboard the boat and possibilities to go out after larger game fish. The cultural interactions that such excursions afford are mutually enriching on many levels.

The tourism sector in Bangladesh currently employs over 1 million people, generating a total value of $\$ 8.4$ million each year [22]. Geographically, Bangladesh is ideally positioned and suited to become an ecotourism destination. It is a river-rich country, with three mighty rivers-the Padma, the Meghna and the Jamuna-each with many tributaries and distributaries, providing many scenic locations surrounded by pristine jungles, dramatic waterfalls, and exotic wildlife in the hilly districts [23]. Thus, there are abundant opportunities for recreational fishing in Bangladesh which can bring much benefit to the country and can function as an essential tool for sustainable human development; including poverty alleviation, employment generation, and the development of rural areas. Several studies are focusing on the potential of tourism and eco-tourism in Bangladesh (see the supplementary 
materials-Table S1). However, they have either focused on the general status of tourism for the whole of Bangladesh or specific tourist sites. Thus, relatively little is known about the current state of the $\mathrm{FbE}$ sector, and limited studies are focusing on the potentials of FbE in Bangladesh. To address this knowledge gap, the present study considers the questions:

- How much potential does Bangladesh have to expand $\mathrm{FbE}$ ? and

- What possible challenges might arise in the implementation of $\mathrm{FbE}$ in Bangladesh?

To answer these questions, this study will review the status quo of tourism in Bangladesh in terms of fisheries sectors; it will identify the potentials and challenges of FbE. Finally, it will offer a management strategy for $\mathrm{FbE}$ in Bangladesh and make recommendations for its implementation. The findings of this study will contribute by informing policymakers of the potential for $\mathrm{FbE}$ and recommendations made here could also be applied in other countries with similar ecological and socio-economic contexts.

\section{Conceptual Framework}

Sustainable tourism has been defined by the United Nations' World Tourism Organization (UNWTO) as: "Tourism that takes full account of its current and future economic, social and environmental impacts, addressing the needs of visitors, the industry, the environment, and host communities" [24]. We adopted the sustainable tourism framework concept of Janusz and Bajdor [25] as the conceptual framework for this present study (Figure 1). The appeal of their concept was its balanced grounding in environmental, social, and economic matters. Sustainable fishing tourism activities should be characterized as follows [24]:

- Making the best use of natural resources, proper environmental management processes and efforts to preserve biodiversity.

- Demonstrating respect for the socio-cultural identity of the local community, and working towards the preservation of cultural and traditional values, as well as enabling intercultural understanding and tolerance.

- Guaranteeing real and lasting economic progress in the society by enabling all of the actors involved to have stable employment and access to increased income-earning opportunities.

Also, sustainable tourism is highly dependent on the ability to increase the financial benefits, achieved by all participants involved in the tourism sector, including the ability to support social, cultural, and environmental heritage [25].

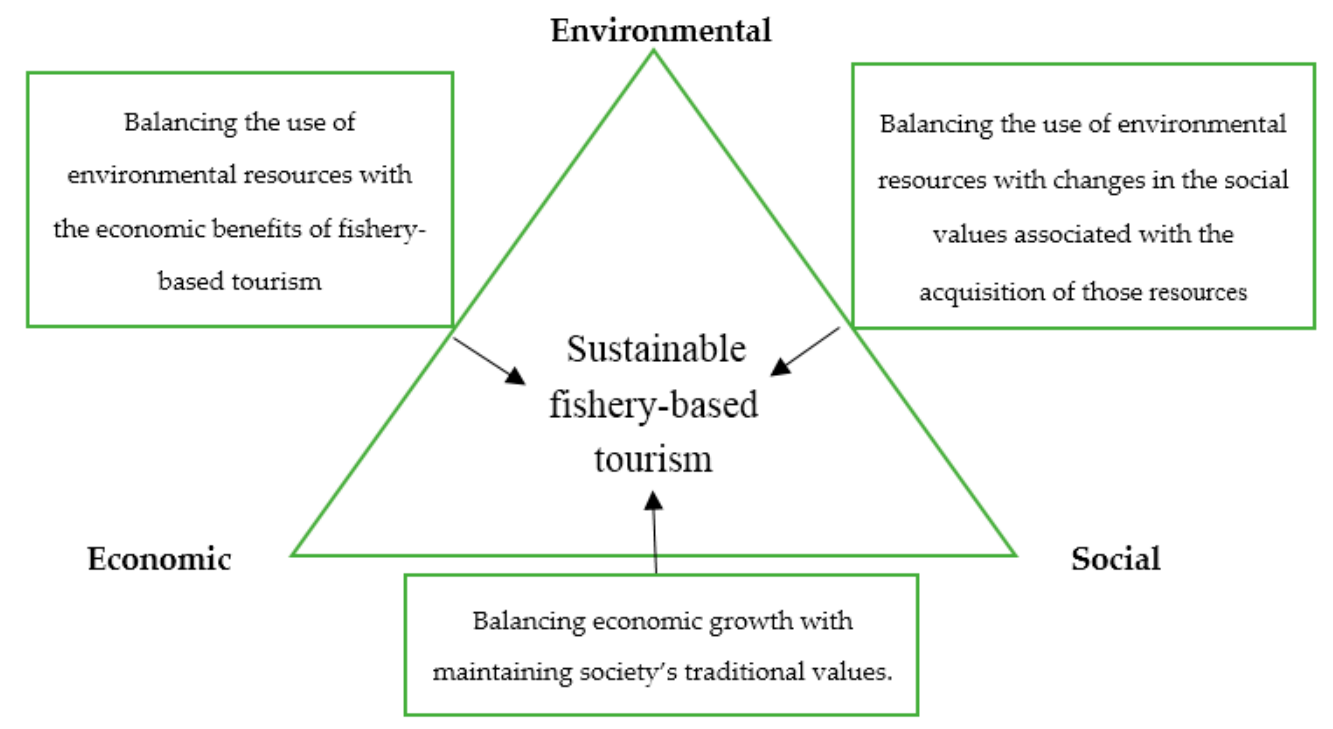

Figure 1. Adopted conceptual framework of sustainable fishery-based tourism [25]. 


\section{Methods}

\subsection{Study Areas}

The geographical areas considered in the present study as potential sites for fisheries tourism in Bangladesh (Figure 2) are the following:

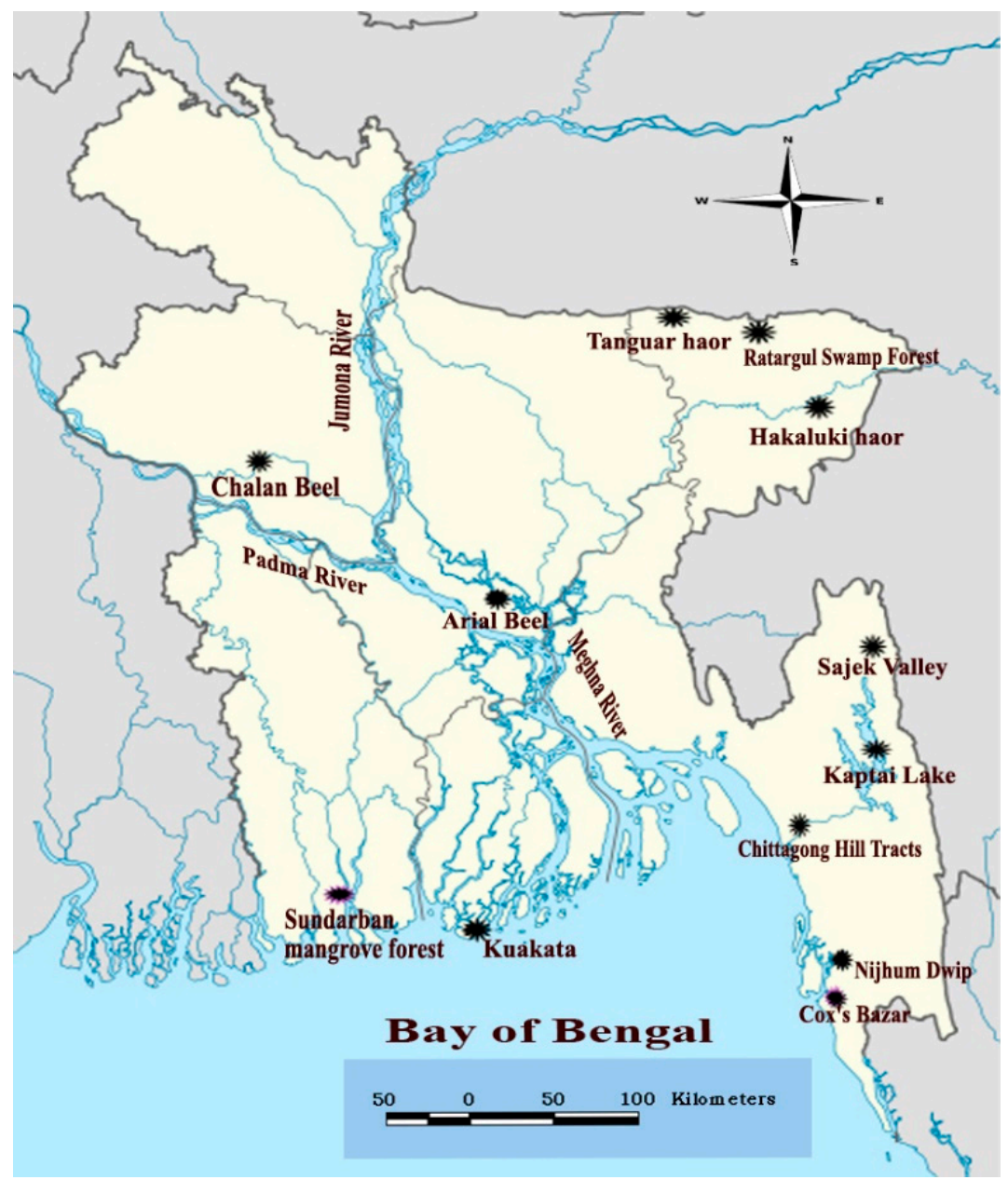

Figure 2. Location of Bangladesh in the world map and fisheries tourism spots in Bangladesh.

- the Sundarban Mangrove Forest-a world heritage site which covers approximately $10,000 \mathrm{~km}^{2}$ and recognized as the largest mangrove forest in the world,

- Cox's Bazar-the current tourist capital of Bangladesh, attracting both international and domestic tourists for its beaches, rainforest, and wildlife,

- Nijhum Dwip—a cluster of islands covering $164 \mathrm{~km}^{2}$ and holding the second-largest Mangrove forest in Bangladesh,

- Kuakata-Bangladesh's second-largest sea beach, located in the south-eastern part of the country,

- Tanguar haor-a unique wetland ecosystem, covering $100 \mathrm{~km}^{2}$ in the Sunamganj district of Bangladesh,

- Hakaluki haor-another vital wetland resource, covering $180 \mathrm{~km}^{2}$, which is wholly inundated during monsoons,

- Chalan Beel一a massive wetland area covering around $1600 \mathrm{~km}^{2}$ spread across three districts in the North-Western part of Bangladesh,

- Arial Beel—Bangladesh's second-largest wetland, covering $136 \mathrm{~km}^{2}$, 
- Kaptai Lake - created by damming the Karnaphuli River near Kaptai in the Rangamati district in 1961, and one of the most significant human-made freshwater resources in South-East Asia,

- The Ratargul Swamp Forest-a freshwater swamp forest sometimes referred to as the Amazon of Bangladesh,

- The Chittagong Hill Tracts-through the districts of Rangamati, Khagrachari, and Bandarban districts, a mass of hills carved with the valleys of the Karnapuli, Feni, Shangu and Matamuhuri rivers, dotted with dramatic cliffs and ravines, and covered with dense jungles, and bamboo forests,

- The major rivers of Bangladesh—-the Padma, the Jamuna and the Meghna,

- The Bay of Bengal-the world's largest bay, located in the northeastern part of the Indian Ocean, bordered by India, Bangladesh, and Myanmar.

\subsection{Research Methods}

This study is based on a synthesis of secondary and primary data, assessed using qualitative methods. A qualitative methodology is most suitable for the exploration of a phenomenon within its context and considered from a broader range of perspectives. It provides a range of lenses through which to view the phenomenon, allowing for multiple aspects to be revealed and understood [26]. Qualitative methods are further suitable for considering our subject matter, because they take all data to be symbolic representations which need to be interpreted in subjective and contextual ways [27]. This is especially important concerning the questions of balance inherent to our conceptual framework. A qualitative approach enabled us to consider our respondents' areas of expertise more flexibly. Then finally in this regard, since $\mathrm{FbE}$ has yet to become fully operationalized in Bangladesh; we cannot yet analyze its statistical ramifications quantitatively, and thus we come to a qualitative methodology somewhat by default.

Primary data were collected through in-depth individual interviews with tourism stakeholders of the following categories: eco-tour operators, angling club members, non-governmental organizations (NGOs), environmental specialist, restaurant owners, travel agencies, artisanal fishers, academics, and officials from the Ministries of Civil Aviation and Tourism during November and December of 2017. Ninety in-depth interviews were conducted, with ten interviewees from each stakeholder group. In-depth individual interviews provided us with an understanding of details regarding each interviewee's personal and cultural perspectives, life experiences and economic circumstances as expressed in their own words [28]. Interviews were semi-structured, which allowed for free-flowing conversation as well. At the beginning of the interview, interviewees were presented with the idea of fishing tourism as a conversation starter. They were then asked what they knew or thought about the status of eco-tourism in Bangladesh, and whether they felt that allocating resources to the promotion of such in the forests and coastal, marine and freshwater areas of Bangladesh might be worth the investment. They were then asked for their perspectives on the potential benefits and challenges of implementing fishery-based tourism in Bangladesh. From there, the conversation was directed towards what types of initiatives that should be taken by the government and other agencies to overcome such challenges, and what types of management strategies might be implemented for $\mathrm{FbE}$ in Bangladesh. Individual interviews lasted 50-60 min on average, and by prior consent, were audio-recorded.

For secondary information, a literature review related to tourism, ecotourism, fishing tourism, angling, recreational fishing, relevant policy documents in Bangladesh and other countries was conducted using online search engines (see the supplementary materials-Table S1). 


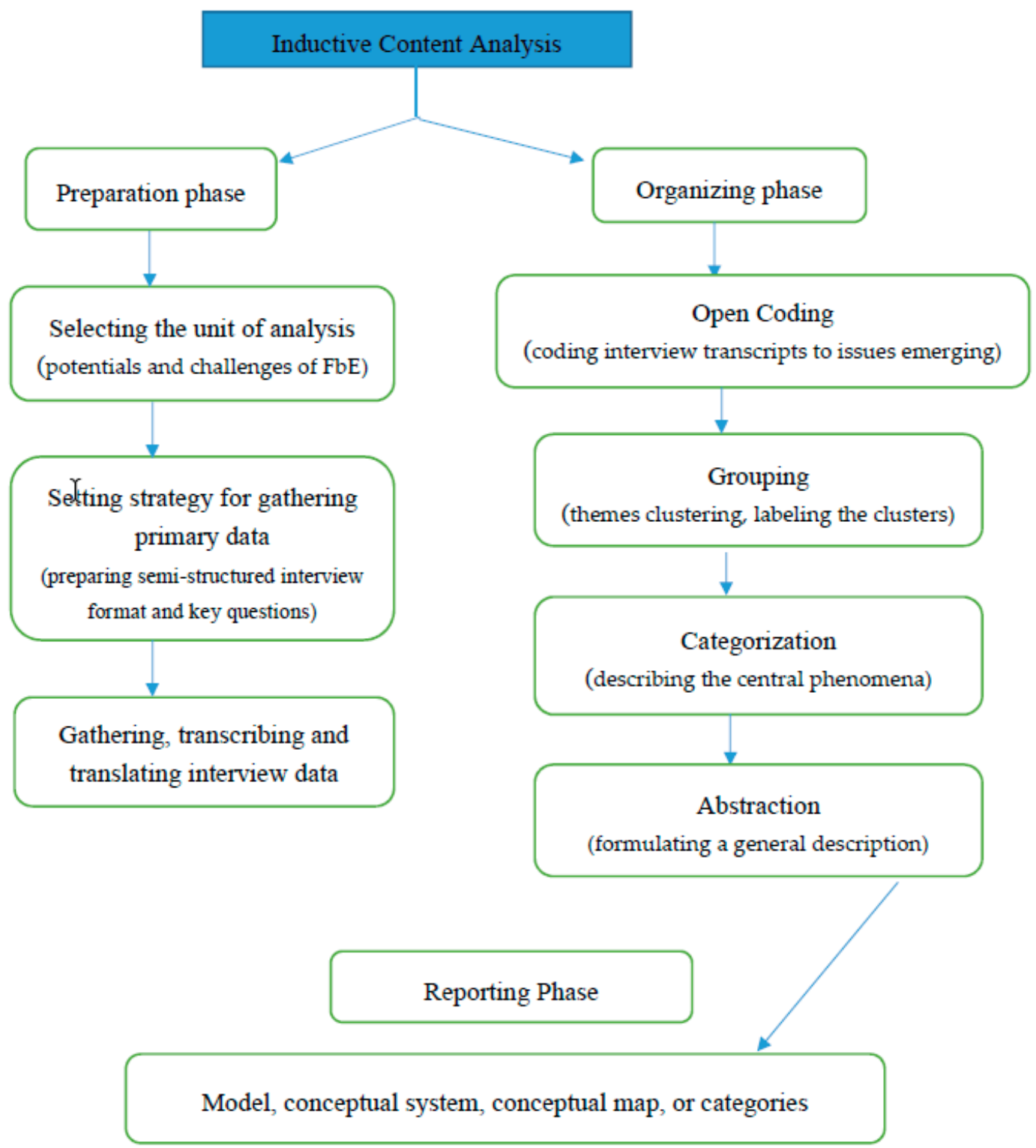

Figure 3. Adopted Inductive Content Analysis diagram [29].

The content analysis method was used for data analyses [30]. More specifically, in this study, we used the inductive approach to content analysis, which is particularly suited to developing new theories or new categories under established ones [31]. The theories we set out to develop were in answer to the questions of how those most directly concerned see the potential benefits and challenges involved in introducing $\mathrm{FbE}$ in Bangladesh's rural fishery areas and along the nation's waterways. The steps involved in the inductive approach to content analysis involved a preparation phase and an organizing phase, and they progressed in a manner seen in Figure 3 above.

The preparation phase included selecting the unit of analysis (potentials and challenges of $\mathrm{FbE}$ ) and devising a strategy for gathering the primary data (setting up a series of semi-structured interviews to provide an overview and holistic perspective on the challenges FbE could entail). During the preparation phase, all the recorded interviews were written in Bengali first and then translated into English. In the organizing phase, the steps included open coding (coding interview transcripts to issues emerging), grouping (clustering themes, and then labeling the clusters), categorization (describing the central phenomena), and abstraction (formulating a general description of the research topic in terms of the categories generated) [32]. 
We clustered interview material according to issues that stakeholders felt should be considered in the process of promoting and implementing $\mathrm{FbE}$. As a result of inductive content analysis, the following data categories were formed: (i) the present status of tourism, ecotourism and fishing tourism in Bangladesh, (ii) potential for $\mathrm{FbE}$ in the aquatic systems of Bangladesh, (iii) possible negative impacts of $\mathrm{FbE}$, (iv) practical challenges entailed in $\mathrm{FbE}$, (v) management strategy to enhance $\mathrm{FbE}$ in Bangladesh. From there, we connected the proposals for $\mathrm{FbE}$ arising within our primary data with the existing literature in the field, enabling us to discuss some little-examined issues regarding FbE. We illustrate the key findings from our empirical material with direct quotations which exemplify the categories into which portions of the interview transcripts were clustered. No qualitative data analysis software was used in this study; all of the analysis here was carried out manually.

\section{Results and Discussion}

\subsection{Present Status of Tourism and Ecotourism in Bangladesh (Secondary Source Findings)}

Tourism in Bangladesh is a developing industry. In the year 2016, nearly 200,000 visitors from abroad visited Bangladesh for different purposes, and by 2027 that number is forecast to rise by approximately $20 \%$ [33]. Several studies have been conducted focusing on the potential for tourism and eco-tourism in Bangladesh (see the supplementary material-Table S1). The potentiality and sustainability of eco-tourism in Bangladesh largely depends on a steady flow of visitors coming to the country, without significantly damaging the natural resources the tourists have traveled there to appreciate in the process [34]. Making Bangladesh a money-making eco-tourism destination will require political stability, a positive approach by the government, active participation by the local population, and smooth and effective promotional campaigns both locally and internationally [35].

In Bangladesh, there is no compelling national tourism plan to guide entrepreneurs and investors. Nor has Bangladesh historically ever made any concerted effort at exploiting its tourism potential. Furthermore, there is a severe lack of management in this sector at the national, regional and local levels [36]. All of this needs to change if Bangladesh wants to utilize tourism as a means of promoting national economic development and societal progress. Recently, however, there have been publicity campaigns from both the public and private sectors to develop awareness of the possibilities for tourism in the country [37]. The government enacted an ordinance in May 2010 which empowers it to designate an area as a tourism site and to control the development of such areas [38]. This law may help motivate the relevant authorities to start identifying potential tourism areas in the country [39]. Prompt identification and designation of tourist attractions could get momentum for tourism development started in the country. Both investors and consumers would then be progressively motivated to take advantage of these potential opportunities [37].

\subsection{Potentials of FbE in the Aquatic Systems of Bangladesh (Secondary Source Findings)}

Bangladesh is considered one of the most suitable regions for fisheries in the world, with the world's largest flooded wetland and the third-largest aquatic biodiversity in Asia, after China and India [40]. Approximately 260 species of freshwater fish are found in the inland water bodies of Bangladesh, and the fisheries can broadly be classified into three categories: inland capture fisheries, inland aquaculture, and marine fisheries [41]. These fisheries also play a vital role in the national economy, adding $3.69 \%$ to Bangladesh's GDP [42]. The total length of the rivers is $24,140 \mathrm{~km}$ that covers $8 \%$ area of the country [43]. Also, the river system of Bangladesh has been categorized into five major networks. The Jamuna-Brahmaputra system $(292 \mathrm{~km})$, the Padma-Ganges system $(258 \mathrm{~km})$, the Surma-Meghna system $(669 \mathrm{~km})$, the Padma-Meghna system $(145 \mathrm{~km})$ and the Karnaphuli system $(420 \mathrm{~km})$ [44].

Fisheries tourism can be divided into two segments (freshwater fishing and marine water fishing) based on Bangladesh's geographic position. Bangladesh has an enormous area of wetlands including rivers and streams, freshwater lakes, and marshes, haors, baors, beels, water storage reservoirs, fish 
ponds, flooded cultivated fields and estuarine systems with extensive mangrove swamps. Haors, baors, beels, and jheels are of fluvial origin and are commonly identified as freshwater wetlands. Also, they play an essential role in the ecology, economy, and livelihood of the country. Bangladesh is estimated to possess $70,000-80,000 \mathrm{~km}^{2}$ of wetlands in the form of permanent rivers and streams $\left(4800 \mathrm{~km}^{2}\right)$, estuarine and mangrove swamps $\left(6100 \mathrm{~km}^{2}\right)$, shallow lakes and marshes $\left(1200-2900 \mathrm{~km}^{2}\right)$, large reservoirs $\left(900 \mathrm{~km}^{2}\right)$, small ponds and tanks (1500-1800 $\left.\mathrm{km}^{2}\right)$, shrimp ponds $\left(900-1150 \mathrm{~km}^{2}\right)$ and seasonally flooded floodplains $\left(57,700 \mathrm{~km}^{2}\right)$ [45].

\section{Qualitative Interview Findings}

Findings of qualitative interviews indicated both prospects and constraints on the implementation of $\mathrm{FbE}$ in Bangladesh. One academic stated during his interview that, "Besides rivers, Bangladesh offers a beautiful opportunity for marine sports fishing in the Bay of Bengal. It has more than $120 \mathrm{~km}$ of shoreline and many hotels and resorts to support both shoreline and deep-sea fishing. So, the whole country can be considered as an angling ground." Citing fishery-based tourism as a new concept in the Bangladeshi context, the head of a tourism association stated: "Fishery-based tourism exists in Bangladesh on a lesser scale. There are some private tour operators and angling clubs that arrange fishing trips in the rivers to do basic spin-casting or fly fishing." Furthermore, some of the potential options for fishery-based tourism and how the aquatic systems of Bangladesh can be used in fishing-related tourism were discussed during the interviews with different stakeholders. The discussions can be summarized in terms of the following quotes:

- A government official from Bangladesh Parjatan Corporation (BPC) said: "Going out with the fishers, listening to their stories, watching them while they haul in their nets and collect the catch; spending a day spent on board a fishing boat one can almost become a skilled fisher. Tour operators can arrange such excursions for both local and foreign tourists in the rivers and the Bay of Bengal. However, the fishing boats would have to be equipped with standard lifesaving equipment, and their crews would need to be properly trained as well."

- A local tour operator from Chittagong stated: "One FbE activity related to tourism can be to arrange fishing tournaments all over the country (in the big rivers, lakes, wetlands and big ponds) for local and foreign tourists. These events are sport fishing competitions that generate significant revenue for the host communities, both by attracting anglers to compete and by creating a festive atmosphere for attendees. In addition to the tourism-related benefits, tournaments can offer means of voluntary data collection, increased fishing license revenues, promotion of the quality fishing available and the possibility to increase sales for the tournament's sponsors." Related to the same issue, an academic said: "To promote the conservation of game fish as well as responsible and ethical angling practices, tournament organizers can develop angling rules oriented towards no-kill fishing and minimizing post-release mortality of the fish caught. Tagging of fish and other citizen science initiatives are also commonly promoted through angling clubs."

- An expert angler stated regarding the possibilities for fly fishing in Bangladesh: "Fly fishing is widely practiced in India, Nepal, and Bhutan. Fly fishing may open tremendous opportunities for sports fishing in Bangladesh as well. However, the sorts of aquatic insects and larvae which the fish naturally live off of in the rivers of Bangladesh have their character, so to make it work, the flies used in this sport would have to be appropriately matched to those in the local environment."

- An eco-tour operator from Cox's Bazar said: "Saltwater angling has not been widely practiced in Bangladesh, though the country is full of potential for saltwater angling adventures in the Bay of Bengal. The potential and possibilities for saltwater fishing in Bangladesh are beyond description! Some systematic survey of these hidden treasures needs to be done so that everyone knows about them. The government should take steps to produce a major advertising campaign to attract anglers and fishing tourists or from all over the world."

- Hilsa (Tenualosa ilisha) is the single most valuable species of fish in Bangladesh's fisheries-regarding sales, employment and even cultural identity. Hilsa is often hailed as 
the "Queen of fishes" and is known for its unique aroma. During the interviews, a restaurant owner from Sundarban mangrove areas added: "There is something very special to the local people about cooking up the freshest possible hilsa, right on the boat while still out on the big rivers. So one thing that can be arranged as part of FbE is these sorts of fishing and dining cruises, for locals as well as for international tourists."

\subsection{Possible Impacts of FbE}

Tourism, in general, can bring many economic, social, and environmental benefits, particularly in rural areas and developing countries [46]. This is, even more, the case with fisheries tourism. An academic from the Department of Economics at the University of Chittagong, expressed his perspective regarding the economic benefits of tourism, including fishing tourism, as follows: "Tourists are an economic force which enhances the government's monetary base. Tourists pay taxes like most other people. Since they come from different regions or countries, their expenditure stands for an increased tax base for the host government. The fishing tourism industry also helps the private sector by generating income as wages for households. Various jobs related to tourism create wages for the family. Furthermore, fishing tourism can cause businesses to flourish — both for local businesses and larger corporations - such as hotels, tour operators, travel agencies, marketing consortiums. Through the creation of new employment opportunities, out-migration, as well as poverty, can be reduced."

Another respondent, a fisher from the Sundarbans mangrove forest area, stated his opinion about integrating fishery operations and tourism thus: "I have been fishing for the last 20 years. I have not heard about fishery tourism before. This is a new thing for me, and I would not have imagined that something like $\mathrm{FbE}$ can be carried out in the Sundarban mangrove forest. Well, we fishers in this mangrove area catch fish in the local rivers and sell the catch on the market or consume it ourselves. I have seen people come here to see the beauty of the forest from other parts of the country and even from abroad. However, there are lots of small rivers and canals, and a variety of fish found in the mangrove forest. In my opinion, there is much potential for integrating fishery activities and tourism in this mangrove forest. Such initiatives may attract more tourists that will increase economic activity and ultimately bring prosperity to the local community. No doubt, fishing tourism would merely supplement our primary income (from fishing) rather than replace it."

Socially, tourism has an enormous influence on host societies. In addition to revenue, fishing tourism can bring a real sense of pride and identity to communities. Also, social contacts between tourists and local people may result in mutual appreciation, understanding, increased tolerance, cultural awareness, learning, family bonding, respect, and even friendships [47]. A representative of one of the local NGOs in the coastal district of Patuakhali, working to support the coastal fishers' welfare, expressed his opinion about the possible social and cultural benefits of fishing tourism as follows: "If it is possible to integrate fishery operations with tourism in this locality, it will create new employment opportunities, hence reducing out-migration as well as poverty. The locals can know the outside world without leaving their homes, while their visitors can learn a great deal about a distinctive culture. Furthermore, local communities benefit from tourism through its contribution to social infrastructure improvements, such as schools, libraries, health centers, and internet cafes. However, we should also be aware of social conflicts that might arise and consider possible ways to mitigate them beforehand."

Furthermore, if local culture is the basis for attracting tourists to the region, this can help to preserve local traditions and handicrafts which might have been on the brink of extinction [48]. Otter fishing, for instance, is a centuries-old tradition in Bangladesh, where fishers have been using trained otters to chase fish into their nets-a rare technique passed on from father to son, that relies on coordination between man and otter. One academic brought up this example during our interviews and said, "Such fishing techniques might be exciting for both locals and foreign tourists to watch. Otter fishing in Bangladesh is on the edge of dying out and arranging exhibitions of this fishing technique for tourists could help preserve the cultural tradition of Bangladesh and may encourage the fishers to hold onto their heritage a bit longer." 
The primary positive impacts of fishing tourism activities would be the sustainable development of the coastal region and the valorization of its historical and socio-cultural vocation and heritage. By recognizing the leading role of professional fishers have played in shaping coastal areas, by promoting the value of local fishery products and, in many cases, by increasing appreciation for traditional artisanal fisheries, $\mathrm{FbE}$ can lead to a reduction in the economic and existential desperation which leads to over-fishing and thus lead to improved conservation of fish and marine resources [31]. During one interview a government official and fisheries specialist from the Department of Fisheries at Cox's Bazar stated his perspective regarding the potential environmental benefits of FbE thus: "Fishery tourism may provide environmental benefits, such as the protection of habitat and fish stocks. However, a collaboration between angler organizations, managers, commercial fishers, and scientists is of great importance, and fishery-based tourism stakeholders should be proactively engaged in fishery management to help develop interdisciplinary management approaches."

\subsection{Challenges of $F b E$}

Tourism, mainly marine and coastal tourism, is one of the fastest growing areas within the world's largest industry [49]. Negative impacts from tourism occur when the level of visitor use is higher than the environment's ability to cope, on account of not keeping changes brought about within acceptable limits [50]. Uncontrolled conventional tourism poses potential threats to many natural areas around the world. It can put enormous pressures on an area and lead to impacts such as soil erosion, increased pollution, discharges of waste into the sea, natural habitat loss and increased pressure on endangered species [51]. Attractive landscape sites, such as sandy beaches, lakes, riversides, and mountain tops and slopes, are often transitional zones, characterized by species-rich ecosystems. Typical physical impacts of tourism include the degradation of such ecosystems [26].

Usually, fish captured by anglers are released. However, there can be substantial post-release mortality if they are not correctly released [27]. In addition to contributing directly to global fishery declines through harvest or mortality, recreational fisheries can contribute to alterations in system function and quality [52]. Discarded fishing line and hooks can foul birds, marine mammals, coral reefs and other marine life, resulting in substantial injury and mortality. Anglers may also disturb wildlife by trampling riparian vegetation to gain access to fishing spots along the shoreline or river banks, or they may increase the nutrient load in the fishery through ground baiting (spreading live bait around in the water close to where they are fishing to draw in fish). Recreational boat traffic and the associated noise pollution, waves, erosion, and scarring also contribute to environmental degradation [20]. Also, solid waste dumped into the waters and pollution coming directly from recreational boats' motors tend to reduce oxygen levels in the water, thereby reducing the chances of survival for aquatic biota [53].

In Bangladesh, despite the immense potential of $\mathrm{FbE}$, there exist several problems along with the above stated global scenarios. According to the respondents of this study, the most prominent issues to be considered were the following:

- Cultural acceptance of fishery-based tourism as a source of livelihood

- Infrastructure development for fishery-based tourism facilities

- Inept promotional activity and lack of tourism awareness among the local people

- Dependence on private sector action and lack of monetary support for the project

- Environmental pollution and unplanned development, particularly in coastal areas

- Security and safety provisions, for local and especially for foreign tourists

- Lack of legislation, regulation, standards, guidelines, and safety codes

- Coordination and integration of the activities of different agencies (Government and non-governmental, fishers, scientists, tour operators, and other FbE stakeholders). 


\subsection{Management Strategy of FbE in Bangladesh}

To set up a sustainable $\mathrm{FbE}$ in Bangladesh, a carefully planned management strategy is needed. Through proper guidelines, it is possible to start $\mathrm{FbE}$ in practice to make the aquatic ecosystems and adjacent landmass a driver for the national economy of Bangladesh. We here propose a strategic framework for FbE management in Bangladesh [22] consisting of three factors (Figure 4): focus on potential sectors, information gathering through study and $\mathrm{FbE}$ governance.

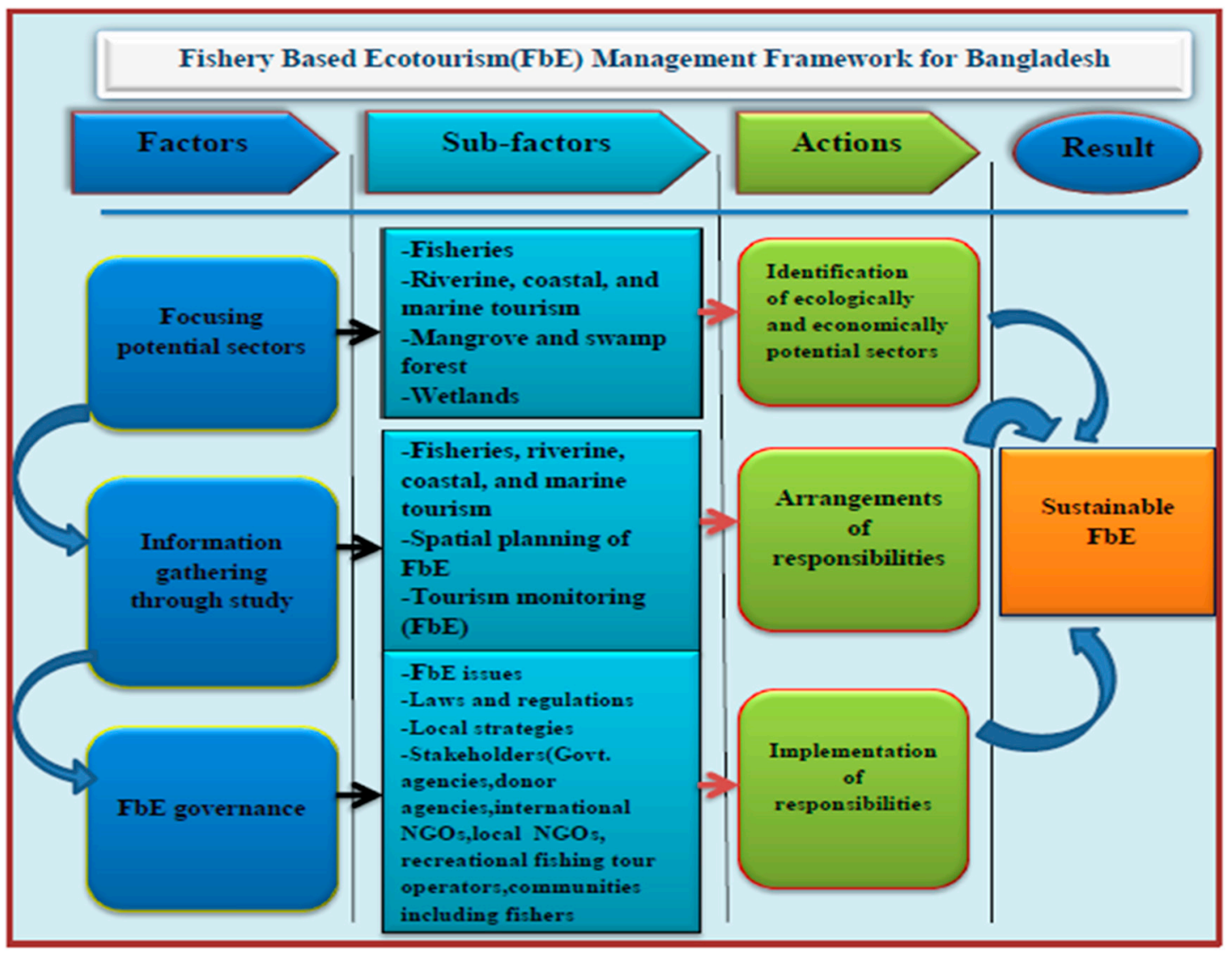

Figure 4. Fisheries-Based Ecotourism (FbE) management framework for Bangladesh [22].

Focusing on potential sectors: A focus on the sectors which have the most significant economic potential (i.e., fisheries; riverine, coastal, and marine tourism; mangrove and swamp forests, and wetlands) is the first key to viable and sustainable $\mathrm{FbE}$ in the country. First, the fisheries sector must progress towards implementing best practices for sustainable fisheries management. It is furthermore crucial that this is done in dialog with pertinent stakeholders. The astonishing beauty and immense variety of aquatic ecosystems in Bangladesh can attract many holidaymakers both from within the country and from abroad, but for this, to work, these ecosystems need to be carefully protected as part of the development process. Thus, the FbE strategy must ensure the smart, sustainable, and inclusive development of the aquatic ecosystems in order to unlock the potential of this promising sector.

Information gathering through study: Research activities to generate knowledge are essential components in the certainty and security of sustainable FbE. While the positive impact that tourism can have culturally and economically cannot be denied, there are also many risk factors involved for tourist destinations. Even FbE may result in clearly undesirable impacts on the local environment, culture, and lifestyle. Such adverse effects can be lessened, or even prevented, by conducting empirical studies to discover potential problems and practical solutions to them in advance, involving relevant stakeholders in the process. Furthermore, since $\mathrm{FbE}$ is a complex activity involving dynamic social interaction processes that cover several sectors of the economy, joint planning efforts—conducted in 
conjunction with ecological, sociological and economic research initiatives-are necessary to ensure active cooperation between various sectors and stakeholders, so as to reduce the risks of mutual distrust stifling the FbE initiatives [54]. Then, since FbE activities take place in specific localities, their spatial characteristics must be considered in term of spatial planning.

Spatial planning is a tool for organizing tourism activities to ease the integration of this sector with other sectors and areas within a locality or region [55]. Also, spatial planning could be considered a buffer mechanism between the private sector and the public for the benefit of all stakeholders. In general, the benefits of spatial planning are economic, social, and environmental. Hence there is an urgency to research $\mathrm{FbE}$ spatial planning. Furthermore, monitoring of $\mathrm{FbE}$ areas through government administrations (Ministry of Fisheries and Environment, law enforcement authorities-Police, Coastguard, Navy) for environmental safety and security, fisheries control, and cultural heritage will ensure sustainable FbE.

FbE governance: Governance is the exercise of political, economic, or administrative power to manage a country's resources, affairs and societal problems [56]. As tourism is a cross-sectional occurrence, involving a wide range of involved parties (stakeholders) from almost every domain, who have different and often contradictory interests and agendas, decisions about tourism development should be balanced between national and local needs, the private sector and the state, local communities, the communities of citizens, between the tourists and the mass media [57]. FbE governance is about managing and using aquatic systems and resources in a way that keeps the aquatic systems healthy, productive, safe, secure and resilient. To build an excellent FbE governance practice, it is crucial to adopt a comprehensive approach, integrating all aquatic issues (fresh water and marine) in Bangladesh, using a robust set of mandatory environmental rules to ensure the use of aquatic resource sustainably. All in all, applying effective governance strategies, specifically through transparency (all decisions taken by stakeholders in and outside the sector, as well as their enforcement in a manner that abides by the rules and regulations of the particular society and internationally accepted practices), accountability (intention and ability of specific people involved in the community or projects to give an account of their ongoing or future plans and activities and their expenditure and revenue to their colleagues, the general public or authorities so that they can be held accountable if things go wrong) and integration (the critical issues for effective combination comprise population level and technological advancement, research centers and academic institutions as well as related international organizations) would ensure sustainable $\mathrm{FbE}$ in Bangladesh.

Implementation of a FbE management framework: Neither the government alone, nor a single powerful tourism organization, can develop a thriving tourism destination. A variety of public and private sector stakeholders must collaborate in tourism destination planning, decision-making, and management [58]. Effective collaboration not only helps to build secure networks among various stakeholders [59], but it also enables those stakeholders to access the necessary resources to achieve their goals [30]; both of which are crucial for sustainable tourism development [27]. Possible stakeholders in Bangladesh related to the $\mathrm{FbE}$ sector, including research institutes, government agencies, donor agencies, international NGOs, local NGOs, recreational fishing tour operators, and communities including fishers. To implement the proposed framework for $\mathrm{FbE}$ management, integration of all $\mathrm{FbE}$ stakeholders is needed. Overall a co-management approach (sharing responsibilities among different $\mathrm{FbE}$ stakeholders) is vital to implement the proposed framework.

\subsection{Suggestions}

Our results reveal that integration between fisheries and tourism can expand the potential of providing jobs for local communities, especially fishery workers who can become more involved in the tourism sector. Similar research was conducted in Sardinia, Italy, and Taiwan as well [18]. Furthermore, based on literature reviews, observation and interviews with relevant stakeholders, this research analysis has identified the following possible steps or recommendations to develop the integration of fisheries and tourism in Bangladesh: 
- River cruises have become major tourist attractions, giving a boost to the tourism industry. There are hundreds of angling locations around the country yet to be explored and to be put into focus for attracting tourists. Initiatives should be carried out to explore the unfamiliar places.

- Since the people of Bangladesh in the river and coastal areas are friendly in behavior and most believe in hospitality, they would likely utilize an opportunity to increase their family income and accept a role in tourism development. Also, fish landing, and fish processing activities are also appealing to be developed as part of the travel package. Such things can be part of fisheries-tourism activity trip packages in Bangladesh [60].

- By using their specific skills and equipment, small-scale fishers can offer services to tourists (e.g., act as guides along the coast or take people on their boats to watch wildlife). The fishing activity itself may also be a source of extra income, as a tourist may be willing to pay for the opportunity to attend fishers at work. Some fishers may even be able to offer accommodation in traditional fishing cottages as an added activity. Beyond this, tourists can consume locally produced fish, if there are restaurants or fish shops where they are available, thus creating other opportunities for fishers to market their catch [61].

- For tourists, seafood is an essential local culinary attraction. There is a high demand for local seafood among tourists visiting the region as well as among residents. Experiencing the local fishing culture and heritage is also an essential part of what attracts tourists. Furthermore, restaurants try to buy fresh and local seafood as much as possible. However, there is a need to develop a more consistent supply of sustainably harvested, fresh, regional, and traceable seafood for restaurants [62].

- Local entrepreneurs and infrastructure developers may explore avenues to invest in building hotels, resorts, and recreational centers near coastal areas. Also, the financial institutions should relax their existing money lending policies to encourage borrowers to receive a bank loan to set up new infrastructures.

- NGOs should take the lead to conduct empowerment activities on tourism matters at the local level and can help in tourism promotion. Local influence groups such as regional political parties, cultural organizations, and civil societies may introduce advocacy activities at the policy level to expand the sort of tourism intended to benefit the poor, working to achieve poverty reduction, conservation of natural resources and promotion of traditional cultures, and building peace and stability [49].

- Tourist Sites and natural attractions should be made more easily accessible through introducing a public transportation system. For the development of the tourism industry, Bangladesh needs to develop more basic services such as hotels, resorts and guest houses. Promotion of these services should be done in cooperation between the private sector and the government tourism organization.

- Tourism professionals need to build personal relationships with charismatic and dynamic fishers, to progressively involve them in providing various services and forms of hospitality to tourists. Such relationships can be initiated, for instance, by organizing joint working groups or promotional events.

- Formulating and proper implementation of a long-term strategic plan and positive attitudes towards attractive Bangladeshi sites can easily foster the growth of $\mathrm{FbE}$ in Bangladesh. In this case, a development plan can include recognition of existing systemic problems and identify strategic plans to solve problems with minimal effort and costs, which will guide the system in a desirable direction [23]. First, FbE systems must be formed, led and operated by residents in order to help the local community claim its share of the profits from FbE. This must be complemented by the development of cooperative governance that guarantees an appropriate level of support from the central government, local government and specialist groups, in order to enhance local capacity. Second, tourism operators must strengthen the quality of ecological, cultural and heritage education and interpretive programs, and regularly update information platforms, which will 
strengthen ecotourists' sense of responsibility. Third, ecotourists and operators with an enhanced sense of responsibility must maintain the $\mathrm{FbE}$ system voluntarily. The sustainability of $\mathrm{FbE}$ is based on an understanding of the willingness to bear some inconveniences in the process of maintaining attractions and recognizing the importance of natural resource conservation [63]. For sustainable $\mathrm{FbE}$ development, and to make FbE marketable, emphasis can be given to the following model of 10 A's (Figure 5) which in turn calls for a high degree of interdepartmental involvement as well as clear understanding of the situation and policy by multiple stakeholders [35]. Furthermore, the overall sustainable development plan should reflect every aspect of the diagram below, and a system must be developed that will ensure the effective coordination and integration of the 10 A's with the participation of all stakeholders involved in FbE.

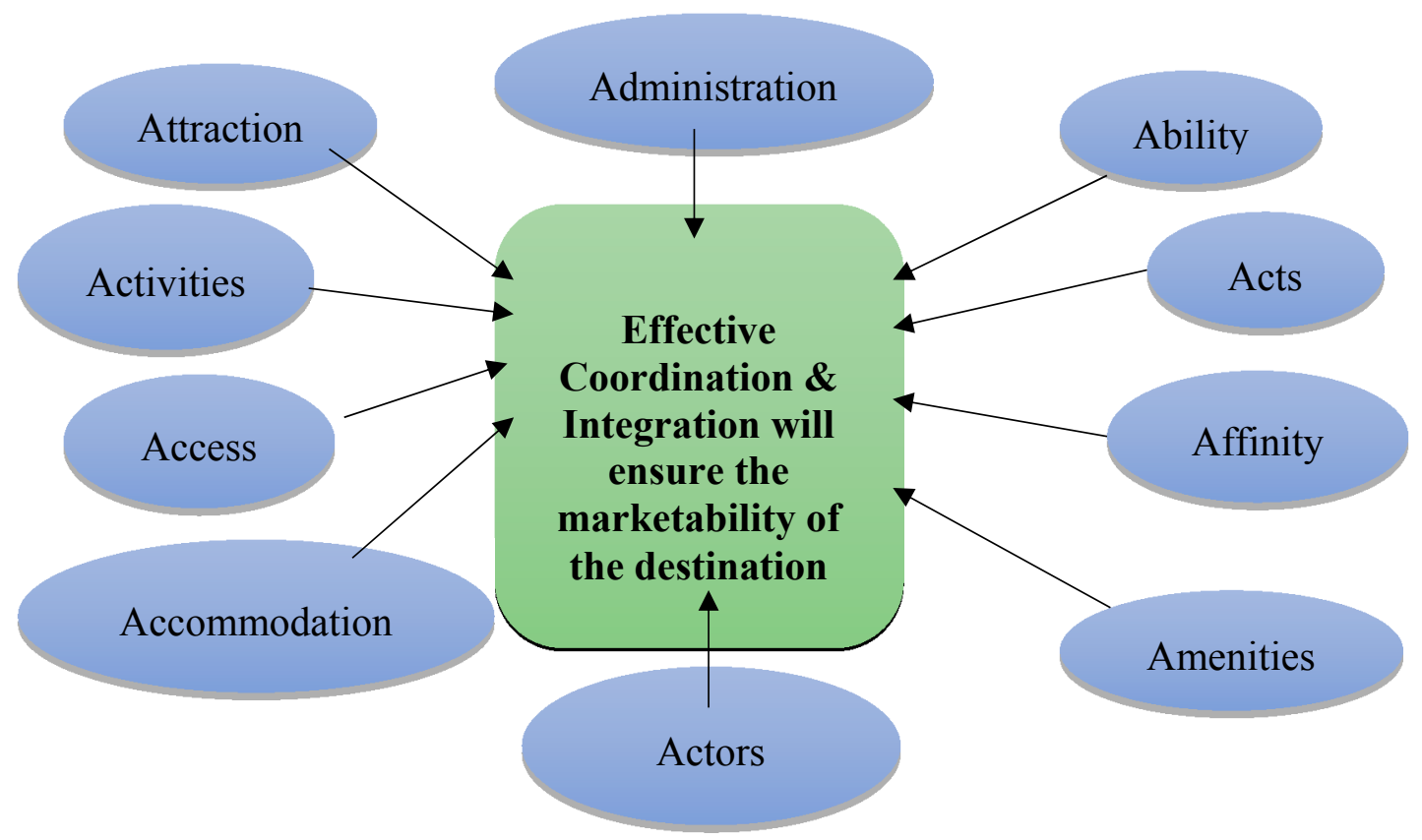

Figure 5. Marketability of a FbE Destination [35].

\section{Conclusions}

The FbE concept is now a standard procedure in the developed countries, while it is still a new concept for the tourism industry in Bangladesh. Furthermore, there are several challenges to the implementation of this concept in Bangladesh, including acceptance of fishery-based tourism as a livelihood effort, the need for infrastructure development, a lack of investment support, risks of environmental damage, a lack of policies for both regulating and promoting this sector, and the need to integrate the concerns of different stakeholders in the process. To foster $\mathrm{FbE}$ and to thereby generate employment in the country and add value to the gross domestic product, the government may come forward and develop a network of building programs that will enhance the abilities of agencies, private sector entities (tour operators, accommodation providers, transport providers) and local fishing communities. They must also take into consideration the interests of local people concerning employment generation, business opportunities, education and infrastructure development. By promoting responsible tourism development and controlling the potential negative aspects of tourism development, the government may begin to create a tourist-friendly environment in areas of the country which have much to offer to visitors and holidaymakers. There is also an urgency to make people understand how 'tourism and fisheries' are connected. The media need to be involved in promoting the possibilities of $\mathrm{FbE}$ as a potential emerging sector in Bangladesh. All in all, FbE in Bangladesh requires fully considering socioeconomic and environmental impacts and minimizing the 
adverse effects on fisheries and fishery products. Appropriately done, FbE could be a practical means of implementing the Sustainable Development Goals (SDGs) in Bangladesh, with a focus on SDG 1 (poverty alleviation), SDG 2 (food security), SDG 3 (healthy life and well-being), SDG 8 (sustainable economic growth), SDG 12 (sustainable consumption and production), and SDG 14 (sustainable use of the oceans and marine resources). We recommend that marketing strategies and an overall $\mathrm{FbE}$ management framework be the bases for action programs, both to meet these goals and to establish Bangladesh as an attractive FbE destination.

The present study is based on literature reviews and in-country interviews. The status of tourism, the potential for $\mathrm{FbE}$, challenges, development of a $\mathrm{FbE}$ framework and recommendations in implementing a FbE framework in Bangladesh are described. The findings of this study can be generalized after considering certain limitations. We considered only published articles and a limited number of interviews with possible stakeholders; while our research strives to be objective, it is indeed not comprehensive. We have not generated sufficient primary data to justify drawing broad scientific conclusions on these matters. Nor is there yet enough secondary source literature available to draw definitive conclusions regarding the current status of $\mathrm{FbE}$ studies from the Bangladeshi perspective.

Regarding further research, it is necessary to consider what would constitute effective governance and conflict resolution mechanisms for FbE. There are knowledge gaps which may need to be filled before recreational fishery tourism or $\mathrm{FbE}$ can be effectively implemented and managed as a practical alternative livelihood strategy. However, the existing theory, synthesis of respondents' perspectives, and the $\mathrm{FbE}$ management framework presented in this study may provide a starting point for thinking about and generating new responsible tourism opportunities linked to small-scale fisheries and ecotourism.

Supplementary Materials: The following are available online at http:/ /www.mdpi.com/2079-9276/7/4/61/s1, Table S1: Studies focusing on the potential of tourism and eco-tourism in Bangladesh.

Author Contributions: M.M.H.M. analyzed data, compiled the draft and finally checked the manuscript. M.M.U. collected data from the field and developed the questionnaire. P.S. and M.M.I. supervised, read and revised the manuscript. Also, M.M.S. read and revised the manuscript.

Funding: This research received no external funding.

Acknowledgments: We are grateful to anonymous reviewers and Subrata Sarkar for the constructive comments and feedback on earlier versions of the manuscript. We also acknowledge all respondents for sharing their perceptions and insights. Special thanks to Tasnim Suruvi, Anik, Arifuzzaman for helping us during the data collection process. We would like to thank David Huisjen, Jr. for his assistance in improving our English here.

Conflicts of Interest: The authors declare no conflicts of interest. The founding sponsors had no role in the design of the study; in the collection, analyses, or interpretation of data; in the writing of the manuscript, and in the decision to publish the results.

\section{References}

1. Sirakaya, E.; Sasidharan, V.; Sönmez, S. Redefining ecotourism: The need for a supply-side view. J. Travel Res. 1999, 38, 168-172. [CrossRef]

2. What Is Ecotourism? Available online: http:/ / ecotourism.org/what-is-ecotourism (accessed on 29 May 2018).

3. Hossen, A.; Ahsan, M.F.; Kamruzzaman, M. Ecotourism potentiality in the Dulahazra Safari Park, Bangladesh. J. Environ. Sci. Nat. Resour. 2015, 7, 189-196. [CrossRef]

4. Clifton, J.; Benson, A. Planning for sustainable ecotourism: The case for research ecotourism in developing country destinations. J. Sustain. Tour. 2006, 14, 238-254. [CrossRef]

5. Dugan, P.; Dey, M.M.; Sugunan, V.V. Fisheries and water productivity in tropical river basins: Enhancing food security and livelihoods by managing water for fish. Agric. Water Manag. 2006, 80, 262-275. [CrossRef]

6. Brummett, R.E.; Beveridge, M.; Cowx, I.G. Functional aquatic ecosystems, inland fisheries and the Millennium Development Goals. Fish Fish. 2013, 14, 312-324. [CrossRef]

7. Fisheries and Tourism Creating Benefits for the Community. Available online: www.webgate.ec. europa.eu/fpfis/cms/farnet/files/documents/FARNET_Fisheries_and_Tourism-9_EN.pdf (accessed on 30 December 2017). 
8. Marine Fisheries Related Tourism in the EU. Available online: www.epthinktank.eu/2016/06/01 (accessed on 24 May 2018).

9. Borch, T.; Moilanen, M.; Olsen, F. Marine fishing tourism in Norway: Structure and economic effects. Økon. Fiskeriforskning 2011, 21, 1-17.

10. Ditton, R.B.; Holland, S.M.; Anderson, D.K. Recreational fishing as tourism. Fisheries 2002, 27, 17-24. [CrossRef]

11. The Economics of Recreational Fishing in America. Available online: http://www.reeladventurefishing. $\mathrm{com} /$ recreational-fishing-reeling-in-big-dollars-for-the-u-s-economy (accessed on 4 September 2018).

12. Arlinghaus, R.; Cooke, S.J. Recreational fisheries: Socioeconomic importance, conservation issues and management challenges. Recreat. Hunt. Conserv. Rural Livelihoods Sci. Pract. 2009, 39-58. Available online: https://www.researchgate.net/publication/227987694_Recreational_Fisheries_Socioeconomic_ Importance_Conservation_Issues_and_Management_Challenges (accessed on 19 June 2018). [CrossRef]

13. Fishing Tourism Profiles. Available online: http://southpacificspecialist.org/fishing-tourism-profiles (accessed on 20 June 2018).

14. Gupta, N.; Raghavan, R.; Sivakumar, K.; Mathur, V.; Pinder, A.C. Assessing recreational fisheries in an emerging economy: Knowledge, perceptions and attitudes of catch-and-release anglers in India. Fish. Res. 2015, 165, 79-84. [CrossRef]

15. Recreational Fishing in Europe. Available online: https://www.eaa-europe.org/files/eftta-jean-claude-bel8-march-2017-final_8374.pdf (accessed on 22 June 2018).

16. Sustainable Tourism in the Mediterranean Region. Available online: http://www.uni-med.net/en/ sustainable-tourism-in-the-mediterranean-region-a-strategic-driver-for-economic-development-thatstrengthens-the-resilience-of-the-maritime-and-coastal-ecosystems-2 (accessed on 20 June 2018).

17. Regional Geography and Economy of the European Countries. Available online: http://unipub.lib.unicorvinus.hu/1672/1/ISP_Textbook_Tozsa.pdf (accessed on 21 June 2018).

18. Chen, C.L. Diversifying fisheries into tourism in Taiwan: Experiences and prospects. Ocean Coast. Manag. 2010, 53, 487-492. [CrossRef]

19. GLOBEFISH-Analysis and Information on World Fish Trade. Available online: www.fao.org/in-action/ globefish/publications/details-publication/en/c/1013325 (accessed on 24 May 2018).

20. Meneghello, S.; Mingotto, E. Promoting sustainable development through fisheries-related tourism experiences. Benefits from the integration between fisheries and tourism in Venetian coastal areas. Int. J. Sustain. Dev. Plan. 2016, 11, 447-457. [CrossRef]

21. Moksness, E.; Gjøsæter, J.; Lagaillarde, G.; Mikkelsen, E.; Olsen, E.; Sandersen, H.; Vølstad, J. Effects of fishing tourism in a coastal municipality: A case study from Risør, Norway. Ecol. Soc. 2011, 16. [CrossRef]

22. Sarker, S.; Bhuyan, M.A.; Rahman, M.M.; Islam, M.A.; Hossain, M.S.; Basak, S.C.; Islam, M.M. From science to action: Exploring the potentials of Blue Economy for enhancing economic sustainability in Bangladesh. Ocean Coast. Manag. 2018, 157, 180-192. [CrossRef]

23. Khondkar, M.; Anis, A. Bangladesh as an ecotourism destination. D.U. J. Mark. 2014, 17. Available online: https://www.academia.edu/29091774/BANGLADESH_AS_AN_ECOTOURISM_DESTINATION? auto=download (accessed on 20 July 2018).

24. Buckley, R. Evaluating the net effects of ecotourism on the environment: A framework, first assessment and future research. J. Sustain. Tour. 2009, 17, 643-672. [CrossRef]

25. Janusz, G.K.; Bajdor, P. Towards to sustainable tourism-framework, activities and dimensions. Procedia Econ. Financ. 2013, 6, 523-529. [CrossRef]

26. Cooke, S.J.; Cowx, I.G. Contrasting recreational and commercial fishing: Searching for common issues to promote unified conservation of fisheries resources and aquatic environments. Biol. Conserv. 2006, 128, 93-108. [CrossRef]

27. Heino, M.; Godø, O.R. Fisheries-induced selection pressures in the context of sustainable fisheries. Bull. Mar. Sci. 2002, 70, 639-656.

28. Guest, G.; Namey, E.; Taylor, J.; Eley, N.; McKenna, K. Comparing focus groups and individual interviews: Findings from a randomized study. Int. J. Soc. Res. Methodol. 2017, 20, 693-708. [CrossRef]

29. Elo, S.; Kyngäs, H. The qualitative content analysis process. J. Adv. Nurs. 2008, 62, 107-115. [CrossRef] [PubMed] 
30. McComb, E.J.; Boyd, S.; Boluk, K. Stakeholder collaboration: A means to the success of rural tourism destinations? A critical evaluation of the existence of stakeholder collaboration within the Mournes, Northern Ireland. Tour. Hosp. Res. 2017, 17, 286-297. [CrossRef]

31. Kavallinis, I.; Pizam, A. The environmental impacts of tourism-Whose responsibility is it anyway? The case study of Mykonos. J. Travel Res. 1994, 33, 26-32. [CrossRef]

32. Mishra, S.K. Ethical, Legal and Social responsibility in tourism business. Int. J. Res. Commer. Manag. 2013, 4, 16-19.

33. Travel and Tourism Economic Impact. Available online: www.wttc.org/-/media/files/reports/economicimpact-research/countries-2017/bangladesh2017.pdf (accessed on 25 December 2017).

34. Islam, M.R.; Iftekhar, M.S.; Islam, M.W. Potential of ecotourism development in Bangladesh coast: An overview. Tour. Rev. Int. 2011, 15, 325-336. [CrossRef]

35. Shoeb-Ur-Rahman, M.; Shahid, R.B. A growing dilemma of tourism diffusion and sustainability: Wows and woes for Bangladesh eco-tourism. UTMS J. Ecol. 2012, 3, 57-69.

36. Rahman, M.L.; Hossain, S.N.; Miti, S.S.; Kalam, A.A. An overview of present status and future prospects of the tourism sector in Bangladesh. J. Bangladesh Inst. Plan. 2010, 3, 65-75.

37. Ali, M.M.; Mohsin, C.S. Different aspects of Tourism marketing strategies with special reference to Bangladesh: An Analysis. Bus. Rev. J. Bus. Admin. 2008, 6, 1-3.

38. Khondker, B.H.; Ahsan, T. Background Paper on Tourism Sector. Background Paper for the 7th Five Year Plan; Government of Bangladesh, Planning Commission: Dhaka, Bangladesh, 2015.

39. Shishir, R.; Monsur, A.; Mausumi, R. Opportunities and Challenges of Eco-Tourism Marketing in Bangladesh. Available online: http:/ / www.bea-bd.org/site/images/pdf/new17/96.pdf (accessed on 29 June 2018).

40. Ghose, B. Fisheries and aquaculture in Bangladesh: Challenges and opportunities. Ann. Aquac. Res. 2014, 1, 1-5.

41. Shamsuzzaman, M.M.; Islam, M.M.; Tania, N.J.; Al-Mamun, M.A.; Barman, P.P.; Xu, X. Fisheries resources of Bangladesh: Present status and future direction. Aquac. Fish. 2017, 2, 145-156. [CrossRef]

42. Shamsuzzaman, M.M.; Xiangmin, X.; Ming, Y.; Tania, N.J. Towards Sustainable Development of Coastal Fisheries Resources in Bangladesh: An Analysis of the Legal and Institutional Framework. Turk. J. Fish. Aquat. Sci. 2017, 17, 833-841. [CrossRef]

43. Nature of Riverine Habitat Degradation. Available online: http://archive.thedailystar.net/2005/10/21/ d510211801104.htm (accessed on 4 September 2018).

44. River Systems. Available online: http://countrystudies.us/bangladesh/25.htm (accessed on 4 September 2018).

45. Byomkesh, T.; Nakagoshi, N.; Shahedur, R.M. State and management of wetlands in Bangladesh. Landsc. Ecol. Eng. 2009, 5, 81. [CrossRef]

46. Brohman, J. New directions in tourism for third world development. Ann. Tour. Res. 1996, 23, 48-70. [CrossRef]

47. Marika, V. Ecotourism and Sustainability: Social Impacts on Rural Communities: Case: San Luis Potosí, Mexico. Available online: https:/ / www.theseus.fi/bitstream/handle/10024/63100/Valtonen_Marika.pdf? sequence=1 (accessed on 2 July 2018).

48. Zambrano, A.M.; Broadbent, E.N.; Durham, W.H. Social and environmental effects of ecotourism in the Osa Peninsula of Costa Rica: The Lapa Rios case. J. Ecotour. 2010, 9, 62-83. [CrossRef]

49. Hall, C.M. Trends in ocean and coastal tourism: The end of the last frontier. Ocean Coast. Manag. 2001, 44, 601-618. [CrossRef]

50. Saarinen, J.; Lenao, M. Integrating tourism to rural development and planning in the developing world. Dev. South. Afr. 2014, 31, 363-372. [CrossRef]

51. Davenport, J.; Davenport, J.L. The impact of tourism and personal leisure transport on coastal environments: A review. Estuar. Coast. Shelf Sci. 2006, 67, 280-292. [CrossRef]

52. McPhee, D.P.; Leadbitter, D.; Skilleter, G.A. Swallowing the bait: Is recreational fishing in Australia ecologically sustainable? Pac. Conserv. Biol. 2002, 8, 40-51. [CrossRef]

53. Silva, J.N.; Ghilardi-Lopes, N.P. Indicators of the impacts of tourism on hard-bottom benthic communities of Ilha do Cardoso State Park (Cananéia) and Sonho Beach (Itanhaém), two southern coastal areas of São Paulo State (Brazil). Ocean Coast. Manag. 2012, 58, 1-8. [CrossRef] 
54. Wood, A.L.; Butler, J.R.; Sheaves, M.; Wani, J. Sport fisheries: Opportunities and challenges for diversifying coastal livelihoods in the Pacific. Mar. Policy 2013, 42, 305-314. [CrossRef]

55. Risteskia, M.; Kocevskia, J.; Arnaudov, K. Spatial planning and sustainable tourism as basis for developing competitive tourist destinations. Procedia Soc. Behav. Sci. 2012, 44, 375-386. [CrossRef]

56. Weiss, T.G. Governance, good governance and global governance: Conceptual and actual challenges. Third World Q. 2000, 21, 795-814. [CrossRef]

57. Getz, D. Event tourism: Definition, evolution, and research. Tour. Manag. 2008, 29, 403-428. [CrossRef]

58. Bornhorst, T.; Ritchie, J.B.; Sheehan, L. Determinants of tourism success for DMOs \& destinations: An empirical examination of stakeholders' perspectives. Tour. Manag. 2010, 31, 572-589.

59. Ford, R.C.; Wang, Y.; Vestal, A. Power asymmetries in tourism distribution networks. Ann. Tour. Res. 2012, 39, 755-779. [CrossRef]

60. Wibisono, H.; Rosyidie, A. Fisheries and Tourism Integration: Potential and Challenge in Pangandaran Village. In Advancing Inclusive Rural Development and Transformation in a Challenging Environment, Proceedings of the 7th International Conference and Field Study of Rural Research, Kuala Lumpur, Malaysia, 15-17 August 2016; UTM RAZAK SCHOOL of Engineering and Advanced Technology: Kuala Lumpur, Malaysia, 2016; p. 367.

61. Job, H.; Paesler, F. Links between nature-based tourism, protected areas, poverty alleviation and crises-The example of Wasini Island (Kenya). J. Outdoor Recreat. Tour. 2013, 1, 18-28. [CrossRef]

62. Angelini, A.; Lesueur, M. Interactions between Fishing and Tourism-Case Study of the Saint-Brieuc Country; Study Report, GIFS Project; Les Publications du Pôle Halieutique AGROCAMPUS OUEST: Rennes, France, 2013; p. 46.

63. Choi, Y.E.; Doh, M.; Park, S.; Chon, J. Transformation planning of ecotourism systems to invigorate responsible tourism. Sustainability 2017, 9, 2248. [CrossRef]

(C) 2018 by the authors. Licensee MDPI, Basel, Switzerland. This article is an open access article distributed under the terms and conditions of the Creative Commons Attribution (CC BY) license (http:/ / creativecommons.org/licenses/by/4.0/). 